Page 120, line 45, for Eq. (40) read Eq. (34). line 46 should read 3422 ". $700-0 " .179 \times 0.005-0 " .043=3422 " .656$.

Page 121, column 1, line 2 should read $\Delta \sigma=\mathrm{b}_{6} \Delta \mathrm{p}+\mathrm{U}$

A. J. 62, No. 1249 :

Page 160-161. Several of the plotted points are in error. However, all tabular values for this paper are correct, with the following exceptions:

Page 160, line 49, for $\mathrm{B}-\mathrm{V}+.046$ read +.059 . line 52 , for $\quad-.077$ read -.079 . line 53, for $\quad-0.83$ read -.092 .

Page 161, line 22, for $\quad-.049 \mathrm{read}-.053$.

A. J. 62, No. 1252 :

Page 260, Figure 9 has been interchanged with Figure 12, page 264. The captions, however, are correct where they now stand.

\title{
NEW BOOKS RECEIVED
}

Manual for Observing Variable Stars, Revised Edition, by Margaret W. Mayall, published by the American Association of Variable Star Observers. Price $\$ 1.00$.

\section{NOTICE}

A Symposium on Numerical Approximation sponsored by the Mathematics Research Center, U. S. Army, will be held April 20 to 23 at the University of Wisconsin, Madison. The topics of the Symposium include linear approximation, interpolation, Tchebycheff and other extremal approximations, expansions and algorithms.

One-hour surveys (including a survey of recent Russian literature) and 30-minute research papers will be presented. There will be opportunity for formal and informal discussion. It is intended to have the proceedings of the Symposium published.

Approximately twenty speakers will participate. Among these are the following guests from abroad: L. Collatz, L. Fox, Z. Kopal, C. P. Miller, A. Ostrowski and E. L. Stiefel.

Workers in the field interested in attending the Symposium are urged to write to

Professor R. E. Langer, Director

Mathematics Research Center, U. S. Army

University of Wisconsin

1118 West Johnson Street

Madison 6, Wisconsin 


\section{ADDENDUM}

A. J. 62, No. 1252, p. 267 :

I have just now been informed that Professor Y. Väisäla had already suggested, in I949, in a paper entitled "Om Prisbilliga Jätteteleskop" which appeared in Särtryk ur Populär Astronomisk Tidskrift, 3-4, page 4, Figure 3, a yoke mounting for telescopes which is in principle identical with the mounting described in my above-mentioned paper and denoted as Askania Arched Yoke Mounting.

I must apologize, therefore, for having overlooked that at the time my paper was published, a similar mounting had already been proposed earlier.

Christoph Kühne 